\title{
Degradation of Ochratoxin A by Proteases and by a Crude Enzyme of Aspergillus niger
}

\author{
Luís Abrunhosa', Lúcia Santos², and Armando Venâncio ${ }^{3}$ \\ ${ }^{1,3}$ Centro de Engenharia Biológica, Universidade do Minho, Campus de Gualtar, \\ Braga, Portugal \\ ${ }^{2}$ LEPAE, Departamento de Engenharia Química, Faculdade de Engenharia da Univer- \\ sidade do Porto, Portugal
}

Ochratoxin A is a mycotoxin present in food commodities as cereals, wine, coffee, figs, dried vine fruits or beer and in feeds for animals. The enhancement of its conversion into ochratoxin $\alpha$ is considered to be a way to reduce its presence in the body and, therefore, its toxicity. In this paper we report the ability of several commercial proteases to hydrolyze ochratoxin A into ochratoxin $\alpha$ in different amounts. After an incubation period of $25 \mathrm{~h}$., a significant hydrolytic activity at $\mathrm{pH} 7.5$ for Protease A (87.3\%), and for Pancreatin (43.4\%) was detected. At $\mathrm{pH} 3.0$, a weak hydrolytic activity was detected for Prolyve PAC (3\%). None of the other commercial enzymes tested were able to hydrolyze ochratoxin A in the tested conditions. Also, the isolation of an enzyme extract from an Aspergillus niger strain with very strong ochratoxin A hydrolytic activity at $\mathrm{pH} 7.5$ (99.8\%) is reported. This activity is similar to the activity detected in Protease A. Data about the inhibition effect of ethylenediaminetetraacetic acid and phenylmethanesulfonyl fluoride on the involved hydrolytic enzymes showed that enzymes involved in ochratoxin A hydrolysis are metalloproteins.

Key Words: ochratoxin A; proteases; degradation; ochratoxin $\alpha$; Aspergillus niger

\section{INTRODUCTION}

Ochratoxin A is a mycotoxin with nephrotoxic, teratogenic, hepatotoxic, immunosuppressive and carcinogenic properties produced by several fungi, such as Aspergillus carbonarius, A. niger, A. ochraceus or Penicillium verrucosum, in food and feed products when optimal temperature and humidity conditions are present in the field or in storage units. Ochratoxin A has been shown to be a potent nephrotoxin in a great number of animal species and the cause of renal hypertrophy in pigs (Elling et al., 1985). It is also associated

Address correspondence to Armando Venâncio, Centro de Engenharia Biológica, Universidade do Minho, Campus de Gualtar 4710-057, Braga, Portugal; Tel.: +351253604413; Fax: +351253678986; E-mail: avenan@deb.uminho.pt. 
with the Balkan endemic nephropathy, nevertheless, stronger scientific evidence is needed (Pfohl-Leszkowicz et al., 2002).

Ochratoxin A (Fig. 1A) is an isocoumarin linked through its 7-carboxy group to L- $\beta$-phenylalanine by an amide bond (van der Merwe et al., 1965). This amide bond mimics a peptide bond and is therefore susceptible to the action of hydrolytic proteases (Fig. 1). The isocoumarin moiety is known as ochratoxin $\alpha$ (Fig. 1B) being commonly reported as less toxic than ochratoxin A. For example, ochratoxin $\alpha$ was ineffective as an immunosuppressor when tested in mice, unlike ochratoxin A or (4R)-4-hydroxyochratoxin A which reduced the production of immunoglobulin $M$ and $G$ from 80 to $93 \%$ (Creppy et al., 1983). Also, it was reported that ochratoxin $\alpha$ is, at least, 1000 times less toxic than ochratoxin A to brain cell cultures (Bruinink et al., 1998). Furthermore, ochratoxin $\alpha$ elimination half-life in the body (9.6 h.) is shorter then that of ochratoxin A (103 h.); so, treatments which enhanced the conversion of this mycotoxin into ochratoxin $\alpha$ are considered to be a way to reduce its toxicity (Li et al., 1997).

Ochratoxin A is a stable compound that can be converted into ochratoxin $\alpha$ and L- $\beta$-phenylalanine by heating under reflux for $48 \mathrm{~h}$ in $6 \mathrm{M}$ hydrochloric acid (van der Merwe et al., 1965) or by hydrolysis with carboxypeptidase A (Pitout, 1969). Several decontamination processes of ochratoxin A in food and feeds have been proposed. The more applied strategies use adsorbents such as aluminosilicates or activated charcoal to remove or retain it (Huwig et al., 2001). Others, use chemicals as ammonia or hydrogen peroxide to inactivate ochratoxin A (Chelkowski et al., 1981; Fouler et al., 1994); or dichloromethane to extract it (Bortoli and Fabian, 2002). However, such strategies lead to significant losses in nutritive value and palatability of decontaminated products. Biodegradation is considered to be a better solution for decontamination (Bata and Lásztity, 1999). Several papers reported ochratoxin A degradation by

A<smiles>C[C@@H]1Cc2c(Cl)cc(C(=O)NC(Cc3ccccc3)C(=O)O)c(O)c2C(=O)O1</smiles>

B<smiles>C[C@@H]1Cc2c(Cl)cc(C(=O)O)c(O)c2C(=O)O1</smiles>

Figure 1: (A) Molecular structure of ochratoxin A and (B) ochratoxin $\alpha$. 
different microorganisms or cells cultures. Examples include filamentous fungi (Abrunhosa et al., 2002; Varga et al., 2000), protozoa (Özpinar et al., 2002), bacteria (Piotrowska and Zakowska, 2000; Wegst and Lingens, 1983), yeasts (Schatzmayr et al., 2003) or plant cell cultures (Ruhland et al., 1996). Some ochratoxin A hydrolytic enzymes were also reported. Pitout (1969) presented the in vitro hydrolysis of ochratoxin A by carboxypeptidase A and, in lower amounts, by $\alpha$-chymotrypsin. More recently, a screening of several commercial hydrolases has also identified a crude lipase from Aspergillus niger (Amano) which substantially hydrolyzed ochratoxin A into ochratoxin $\alpha$ (Stander et al., 2000). Despite all these assessments of ochratoxin A biodegradation, strategies to apply these technologies to food processes are not very abundant.

Since, a significant fraction of world food crops are contaminated with mycotoxins safer ways to decontaminate these foods are needed. Enzymes could be a practical way to reduce the levels of these contaminants. In this paper we present data about the ability of several commercial enzymes to hydrolyze ochratoxin A and also, the isolation of a crude enzyme extract from an $A$. niger strain able to hydrolyze this mycotoxin.

\section{MATERIAL AND METHODS}

\section{Enzymes}

Proteases of fungal origin, mainly from A. niger were selected, since in previous works several fungal strains from this species were shown to degrade ochratoxin A (Abrunhosa et al., 2002). Proteases from other sources and some oenological enzymes were also selected for comparative reasons. All enzymes were food grade. Carboxypeptidase A (EC 3.4.17.1 - Sigma, type II-PMSF) from bovine pancreas was used as a reference standard since its activity on ochratoxin A is well known (Pitout, 1969). The principal characteristics of each enzyme are briefly presented in Table 1.

\section{Crude Enzyme from Aspergillus niger}

\section{Biological Material}

Aspergillus niger MUM 03.58 and A. alliaceus MUM 03.55, were originally isolated from grapes and were nonproducer and producer of ochratoxin A, respectively (Serra et al., 2003).

\section{Growth Conditions}

Inocula were prepared by growing the cryopreserved fungi in tubes with MEA medium, Blakeslee formula (Samson et al., 2004), for 7 days at $25^{\circ} \mathrm{C}$ in 


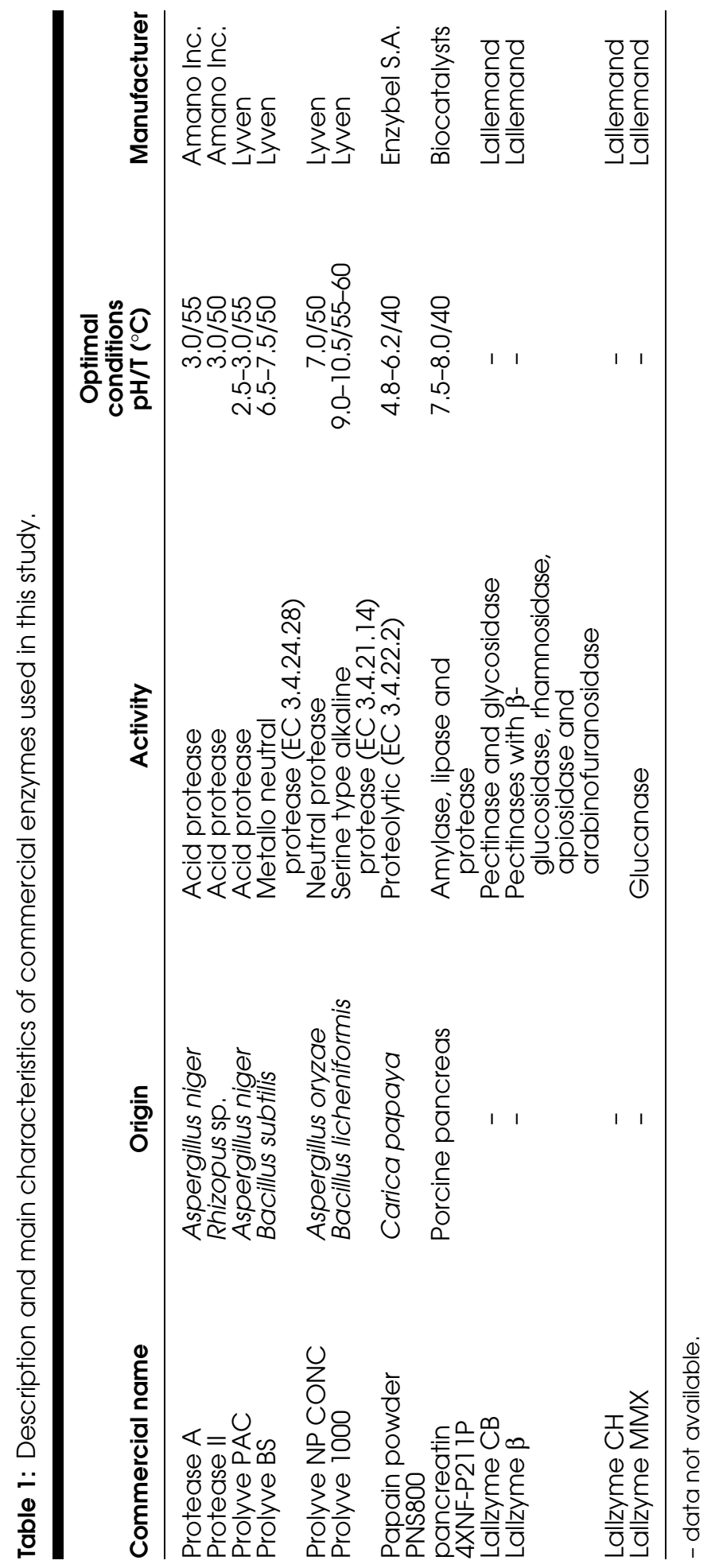


the dark. Then, $4 \mathrm{ml}$ of peptone solution ( $0.1 \%$ peptone and $0.001 \%$ Tween 80$)$ were added and vortexed for $1 \mathrm{~min}$. Spore suspensions were transferred to sterile tubes and $1 \mathrm{ml}$ of each was used in inoculation.

The A. alliaceus MUM 03.55, which was previously found to be a very good producer of OTA (Abrunhosa et al., 2004), was inoculated into $30 \mathrm{~g}$ of dextrinated wheat germ at $45 \%$ moisture, previously autoclaved in a 500-ml flask, and incubated for 16 days at $25^{\circ} \mathrm{C}$ in the dark. After this first step, the flask was autoclaved at $121^{\circ} \mathrm{C}$ for $15 \mathrm{~min}$. and the A. niger MUM 03.58 was inoculated in the resulting substrate, incubation was allowed for 10 more days at $25^{\circ} \mathrm{C}$ in the dark. This procedure was used to grow the A. niger strain in an ochratoxin A containing substract and, this way, induce the synthesis of hydrolytic enzymes.

\section{Crude Enzyme (Ancex) Preparation}

One-hundred $\mathrm{ml}$ of a cold solution of $50 \mathrm{mM}$ citrate/phosphate buffer at $\mathrm{pH}$ 5.6 and $0.24 \mathrm{mM}$ of Triton X100 was added to the flask of the A. niger growth. The substrate was first broken into small pieces and gently mixed with the buffer and allowed to extract for $2 \mathrm{~h}$. by agitation with a magnetic bar at $4^{\circ} \mathrm{C}$.

The resulting homogenate was filtered through a nylon net and squeezed to separate the liquid content from solid residues. The liquid fraction was centrifuged at $604 \mathrm{RCF}$ during $10 \mathrm{~min}$. at $4^{\circ} \mathrm{C}$, filtered through filter paper (500-A from la papelera del besós, S.a.), frozen at $-80^{\circ} \mathrm{C}$ and lyophilized.

The lyophilized sample was resuspended in $10 \mathrm{ml}$ of cold $100 \mathrm{mM}$ phosphate buffer at $\mathrm{pH} 7.5$, then mixed with $20 \mathrm{ml}$ of cold acetone and kept $30 \mathrm{~min}$. in the freezer to allow protein precipitation. Afterwards the sample was centrifuged at $12225 \mathrm{RCF}$ for $15 \mathrm{~min}$. at $4^{\circ} \mathrm{C}$. The supernatant was then discarded and the pellet washed with $10 \mathrm{ml}$ of cold acetone. The sample was again centrifuged under the same conditions and the supernatant discarded. The pellet was air dried and resuspended in $10 \mathrm{ml}$ of the buffer solution at $\mathrm{pH} 7.5$ and preserved at $4^{\circ} \mathrm{C}$.

\section{in vitro Degradation Assays}

Depending on the $\mathrm{pH}$ of the assay different buffer systems were used: $50 \mathrm{mM}$ citrate buffer at $\mathrm{pH} 3.0,50 \mathrm{mM}$ citrate/phosphate buffer at $\mathrm{pH} 5.6$, $100 \mathrm{mM}$ phosphate buffer at $\mathrm{pH} 7.5,50 \mathrm{mM}$ Tris buffer at $\mathrm{pH} 8.5$ and $50 \mathrm{mM}$ carbonate/bicarbonate buffer at $\mathrm{pH} 10.0$ (all reagents from Merck). All buffers were supplemented with $0.1 \%$ of sodium azide (Sigma). Ochratoxin A solutions (at $1 \mu \mathrm{g} / \mathrm{mL}$ ) were made by evaporating the appropriate volume of a stock of ochratoxin A (Sigma) with $25 \mu \mathrm{g} / \mathrm{mL}$ in toluene/acetic acid (99/1, v/v), in several vials. Buffers were added to the dry residues and solubilization was enhanced in an ultrasonic bath (30 min.). Degradation assays were done by incubating $10 \mathrm{mg}$ of each enzyme (or $100 \mu \mathrm{L}$ for Prolyve 1000 and $20 \mu \mathrm{L}$ for Ancex) with $1 \mathrm{~mL}$ of each ochratoxin A solution at $37^{\circ} \mathrm{C}$ for one day. Positive 
assays were tested in the same conditions in the presence of $10 \mathrm{mM}$ of ethylenediaminetetraacetic acid (EDTA) from Merck or $1 \mathrm{mM}$ of phenylmethanesulfonyl fluoride (PMSF) from Sigma. Positive assays were also tested at $50^{\circ} \mathrm{C}$. Assays with $0.5 \mathrm{mg} / \mathrm{mL}$ of carboxypeptidase A (EC 3.4.17.1) and blanks without any enzyme were used as controls.

\section{Sample Processing}

For each assay, one sample of $20 \mu \mathrm{L}$ was collected at $0,3,6,9,15$ and $25 \mathrm{~h}$. and diluted in $980 \mu \mathrm{L}$ of the HPLC mobile phase. Samples were filtered through a $0.45 \mu \mathrm{m}$ Acrodisc GHP membrane filter (Gelman) and analyzed by high-performance liquid chromatography. The HPLC apparatus consisted of a Varian 9002 pump equipped with a Jasco FP-920 fluorescence detector $\left(\lambda_{\text {ex }}=\right.$ $333 \mathrm{~nm} ; \lambda_{\text {em }}=460 \mathrm{~nm}$ ) and a Marathon Basic autosampler. The analytical column was a $\mathrm{C}_{18}$ reversed-phase YMC-Pack ODS-AQ $(250 \times 4.6 \mathrm{~mm}$ and $5 \mu \mathrm{m})$, fitted with a precolumn with the same stationary phase. The mobile phase was a mixture of acetonitrile/water/acetic acid (99/99/2, v/v/v), filtered and degassed. Flow rate was set to $0.8 \mathrm{~mL} / \mathrm{min}$ and the column temperature to $30^{\circ} \mathrm{C}$; the loop volume was $100 \mu \mathrm{L}$. A five point calibration curve $(0.05 ; 0.1 ; 1.0$; 10.0 and $20.0 \mathrm{ng} / \mathrm{mL}$ ) was prepared with standards of ochratoxin A (Sigma) and regularly checked. Ochratoxin $\alpha$ was identified through carboxypeptidase A degradation of ochratoxin $\mathrm{A}$ and quantified in equivalents of ochratoxin $\mathrm{A}$ using the previous calibration curve.

\section{RESULTS AND DISCUSSION}

From all screened commercial enzymes, just Protease A, Prolyve PAC and pancreatin showed ochratoxin A hydrolytic activity. The other tested enzymes were not active against this mycotoxin. Chromatograms showed the reduction of ochratoxin A contents in the samples and its conversion into ochratoxin $\alpha$ (Fig. 2). As mentioned before, ochratoxin A is found in some wines, and strategies for removing this mycotoxin from wines are under evaluation (Ratola et al., 2005) with the application of enzymes being one possible approach.

Figure 3 shows the hydrolysis of ochratoxin A with time and the respective formation of ochratoxin $\alpha$ with time. Protease A, an acid protease from A. niger, had higher degradation capacity of all commercial enzymes tested. This enzyme converted $87.3 \%$ of total ochratoxin A into ochratoxin $\alpha$ after $25 \mathrm{~h}$. when incubated at $\mathrm{pH} 7.5$ and $37^{\circ} \mathrm{C}$. Pancreatin, a mixture of enzymes from porcine pancreas, also revealed a significant ochratoxin A hydrolytic activity. This enzyme was able to convert $43.4 \%$ of the initial ochratoxin A into ochratoxin $\alpha$ under the same conditions. For Prolyve PAC, hydrolytic activity was not detected at $\mathrm{pH} 7.5$, as with the other enzymes; however, at $\mathrm{pH} 3.0$, a small amount activity was detected, whereby $3 \%$ of the initial ochratoxin A was converted into ochratoxin $\alpha$ after $25 \mathrm{~h}$. at $37^{\circ} \mathrm{C}$. 


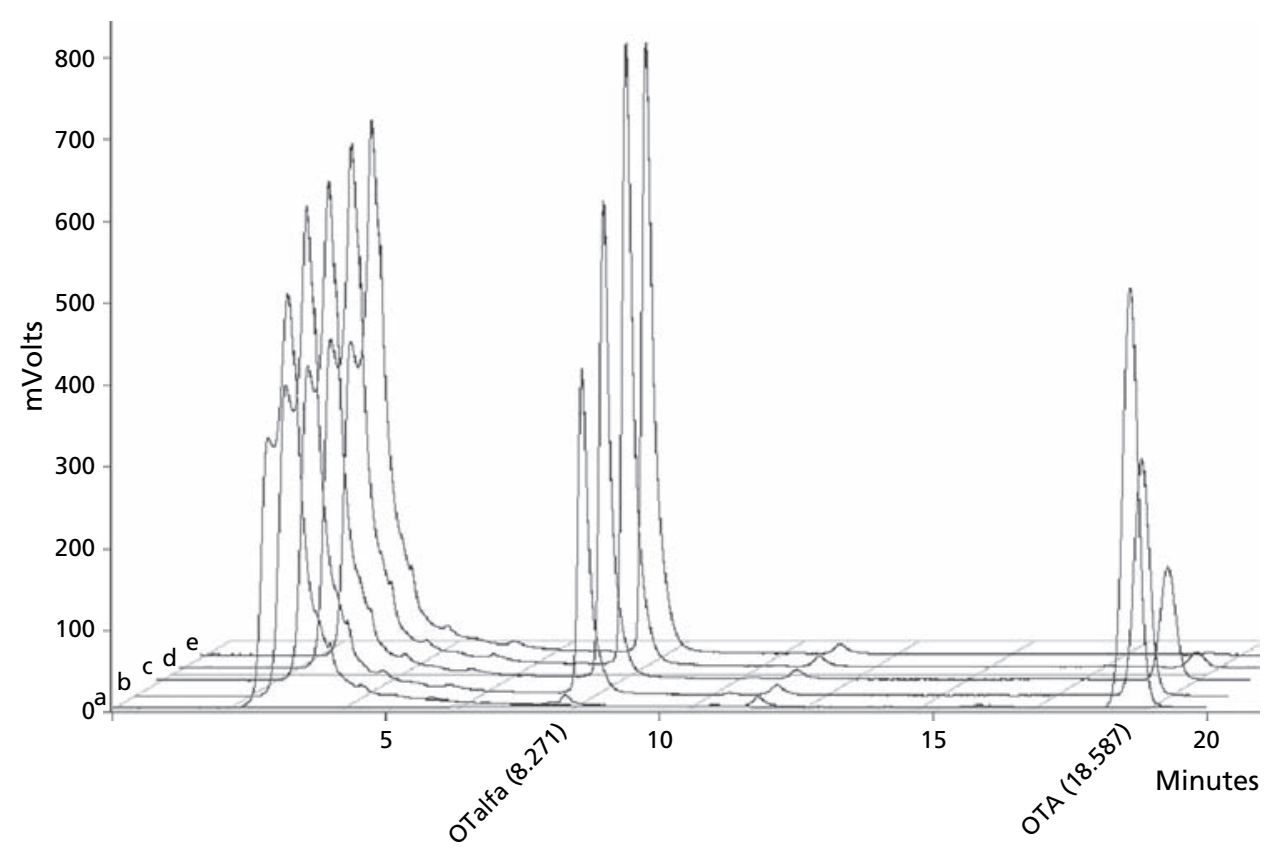

Figure 2: Chromatograms obtained for Ancex at $\mathrm{pH} 7.5$ and $37^{\circ} \mathrm{C}$, showing the hydrolysis of ochratoxin A at a) 0 h., b) 3 h., c) 6 h., d) 15 h. and e) 25 h.

Protease A and Prolyve PAC are products obtained through fermentation processes from selected $A$. niger strains. In a previous study, it was shown that several strains of the $A$. niger aggregate, isolated from grapes, hydrolyzed ochratoxin A (Abrunhosa et al., 2002). Therefore, A. niger MUM 03.58 was used for the isolation of an enzymatic extract that could degrade ochratoxin A. This extract (Ancex) exhibited a higher hydrolytic activity on ochratoxin A when compared with carboxypeptidase A (Fig. 4) where in $99.8 \%$ of the initial ochratoxin A content was converted to ochratoxin $\alpha$ after $25 \mathrm{~h}$. when incubated at $\mathrm{pH}$ 7.5 and $37^{\circ} \mathrm{C}$. The optimal conditions for ochratoxin A hydrolysis by Ancex were the same as for Protease A. Nevertheless, $20 \mu \mathrm{L}$ of Ancex (equivalent to $0.112 \mathrm{mg}$ of protein quantified by the Bradford test) had higher activity than $10 \mathrm{mg}$ of Protease A or $0.5 \mathrm{mg}$ of carboxypeptidase A at pH 7.5 (Fig. 4). It was also observed that Ancex has higher activity at $\mathrm{pH} 5.6$ than the commercial enzymes (Fig. 5A). Furthermore, Ancex activity was greater at $50^{\circ} \mathrm{C}$ than at $37^{\circ} \mathrm{C}$ (Fig. 5B); where in $87.9 \%$ of the initial ochratoxin A content was converted into ochratoxin $\alpha$ after only $3 \mathrm{~h}$. when Ancex was incubated at $50^{\circ} \mathrm{C}$.

A preliminary assessment of the nature of the enzymes involved in ochratoxin A hydrolysis was also done. Estimation of this activity was conducted in the presence of EDTA or PMSF. EDTA is known as a specific inhibitor of metalloproteases and PMSF as a specific inhibitor of serine-type proteases. As shown in Figure 6, EDTA significantly inhibited Protease A, pancreatin, 

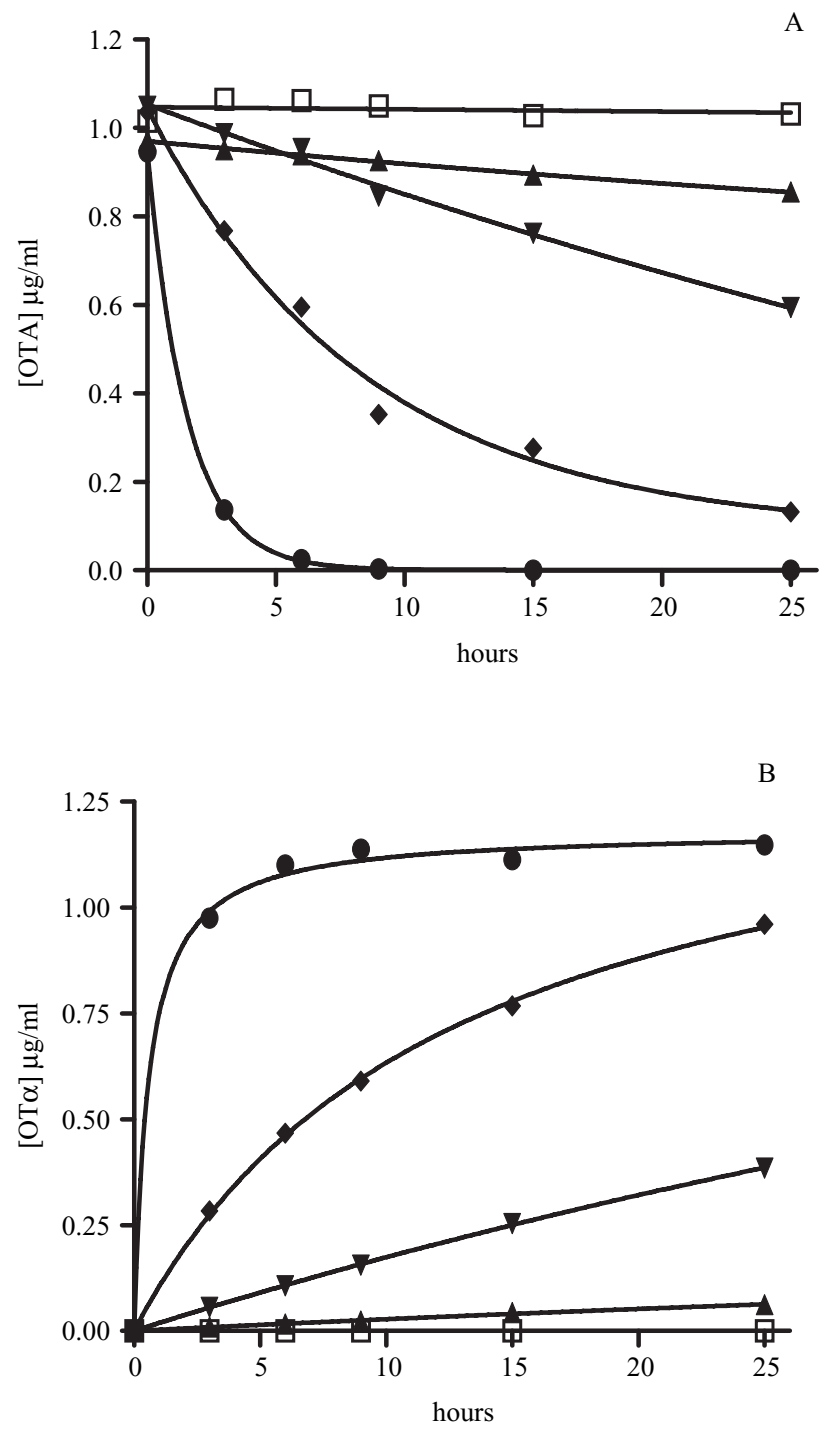

Figure 3: (A) Hydrolysis of ochratoxin A by several enzymes at $37^{\circ} \mathrm{C}$; (B) ochratoxin $\alpha$ concentration detected with time in the same assays. (- $\square-$, Blank; $-\mathbf{\Delta}-$, Prolyve PAC at $\mathrm{pH} 3.0$; - $\mathbf{-}$-, pancreatin at $\mathrm{pH} 7.5$; - - -, Protease $\mathrm{A}$ at $\mathrm{pH} 7.5$ and - $\bullet-$, Carboxypeptidase $\mathrm{A}$ at $\mathrm{pH} 8.5$ )

Carboxypeptidase A and Ancex by 79.6, 90.2, 96.2 and 99.0\% of total degradation capacity, respectively. These enzymes were not significantly inhibited by PMSF. So, these enzymes, involved in the hydrolysis of ochratoxin A, could be metalloproteases similar to carboxypeptidase A. Prolyve PAC was inhibited not by EDTA (1.8\%) but by PMSF (68.3\%). Prolyve PAC activity on ochratoxin $\mathrm{A}$ is probably due to a serine-type protease. 

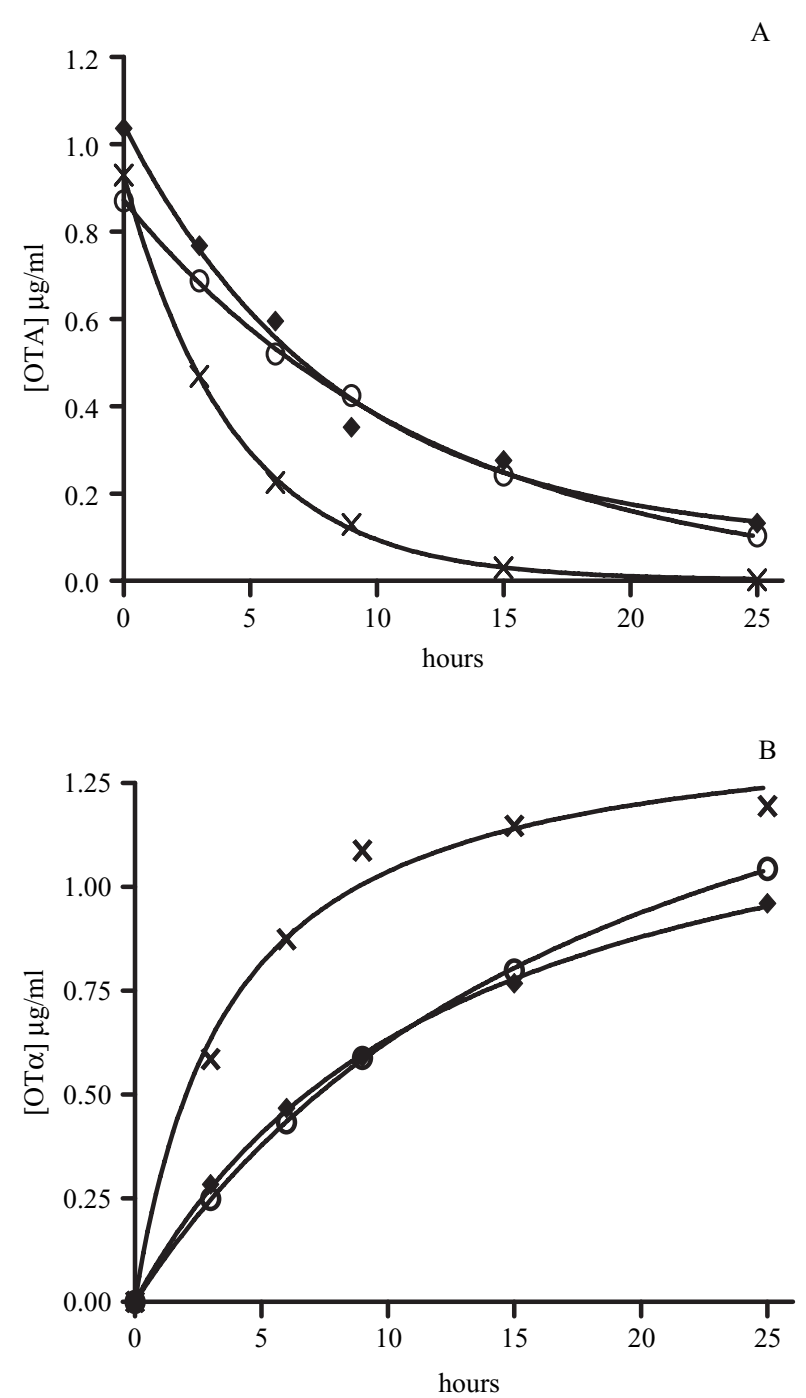

Figure 4: (A) Comparison between ochratoxin A hydrolysis activity of Protease A (- $\uparrow-)$, Carboxypeptidase $\mathrm{A}\left(-\mathrm{O}^{-}\right)$and $\mathrm{Ancex}(-\mathrm{x}-)$ at $\mathrm{pH} 7.5$ and $37^{\circ} \mathrm{C}$; (B) ochratoxin $\alpha$ concentration detected with time in the same assays.

\section{CONCLUSIONS}

An enzymatic extract possessing a high hydrolytic activity of ochratoxin A was isolated from A. niger MUM 03.55. Ochratoxin A hydrolytic activity was also detected on some commercial proteases. This enzymatic extract, as well as Protease A and pancreatin, exhibited a carboxypeptidase A-like hydrolytic activity on ochratoxin A. The oenological enzymes tested were not effective, making these preparations of no added value for ochratoxin A degradation in 

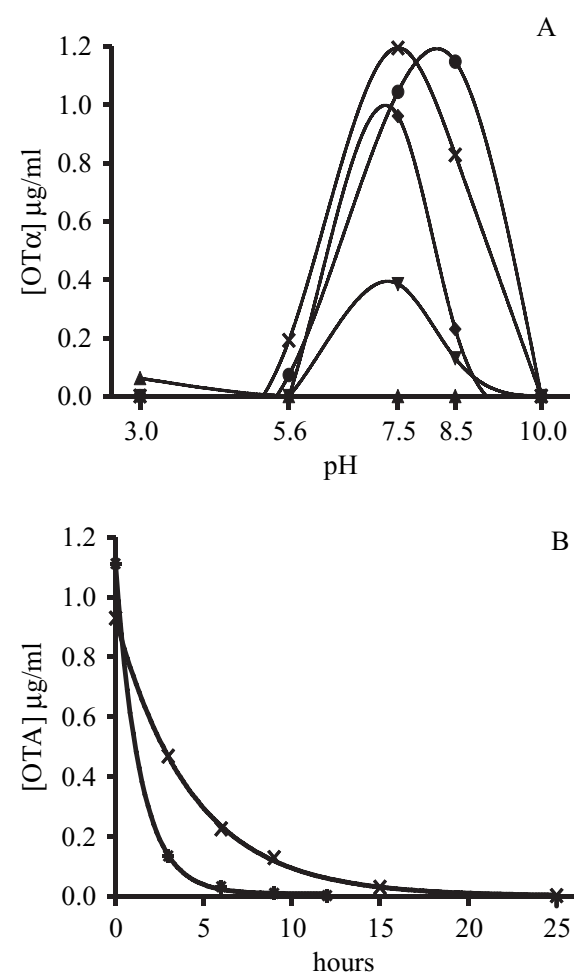

Figure 5: (A) Activity at different $\mathrm{pH}$ and $37^{\circ} \mathrm{C}$ of the enzymes, expressed in ochratoxin $\alpha$ con-

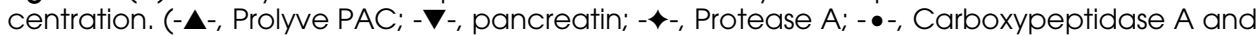
$-x-$, Ancex); (B) comparison between ochratoxin A hydrolysis activity of Ancex at $\mathrm{pH} 7.5$ and $37^{\circ} \mathrm{C}(-\mathrm{x}-)$ and $\mathrm{Ancex}$ at $\mathrm{pH} 7.5$ and $50^{\circ} \mathrm{C}\left(-^{*}-\right)$.

wine or grape must. Only one commercial enzyme was active against ochratoxin $\mathrm{A}$ at an acidic $\mathrm{pH}$ - Prolyve PAC. In some food processing applications, such as juice or wine production, an enzyme preparation with activity against ochratoxin $\mathrm{A}$ in the $\mathrm{pH}$ range of 3 to 5 is more convenient.

Further studies to characterize the ochratoxin A hydrolytic enzyme present in Ancex are in progress, and its application in food or feed processing is under evaluation.

\section{SAFETY}

Ochratoxin A is a toxic compound that needs to be manipulated with care and with appropriate safety precautions. Decontamination procedures for laboratory wastes were employed as reported by the International Agency for Research on Cancer (IARC) (Castegnaro et al., 1991). Because acetonitrile is dangerous (R- 11-20/21/22-36) residues produced during this work were collected in appropriate labelled flasks and properly disposed of. 


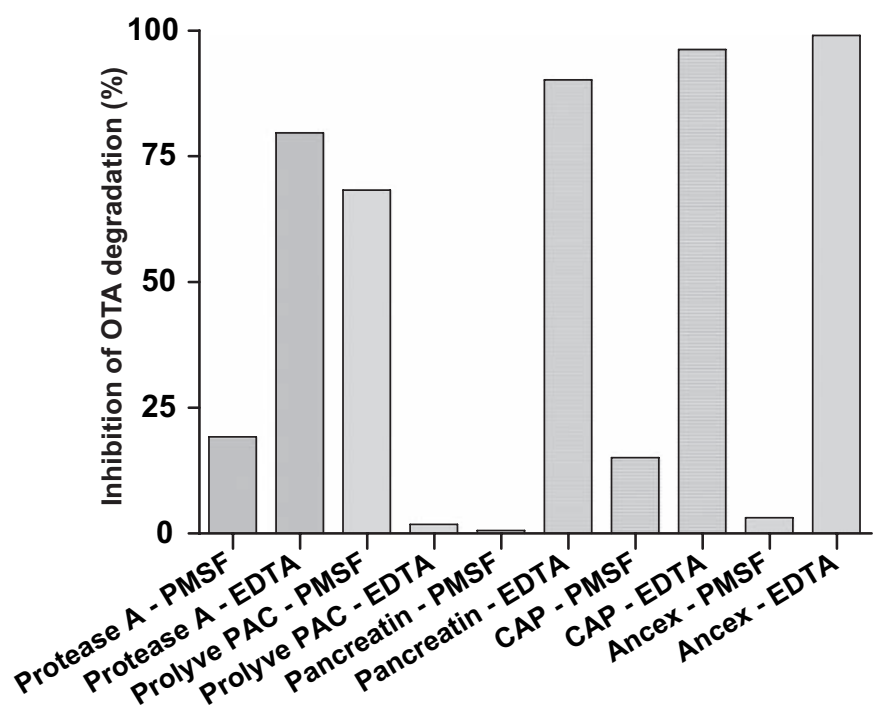

Figure 6: Ethylenediaminetetraacetic acid (EDTA) and phenylmethanesulfonyl fluoride (PMSF) inhibition effect on the ochratoxin A hydrolytic enzymes at $37^{\circ} \mathrm{C}$, expressed in percentage of total activity without inhibitor. (pH 3.0 for Prolyve PAC and $\mathrm{pH} 7.5$ for all the other enzymes)

\section{ACKNOWLEDGEMENT}

Luís Abrunhosa was supported by the grant SFRH/BD/11228/2002 from Fundação para a Ciência e Tecnologia - FCT, Portugal.

\section{REFERENCES}

Abrunhosa, L., Santos, L., Venâncio, A. (2004). Biosynthesis, detection and toxicology of ochratoxins - optimisation of production. The 10th International Congress for Culture Collections (ICCC-10). Tsukuba, Japan.

Abrunhosa, L., Serra, R., Venâncio, A. (2002). Biodegradation of ochratoxin A by fungi isolated from grapes. J. Agric. Food Chem. 50 (25):7493-7496.

Bata, Á., Lásztity, R. (1999). Detoxification of mycotoxin-contaminated food and feed by microorganisms. Trends Food Sci. Tech. 10 (6-7):223-228.

Bortoli, G., Fabian, M. (2002). A process to remove mycotoxins from green coffee. Content at http://www.demus.it/eng_site/micotoxine.htm.

Bruinink, A., Rasonyi, T., Sidler, C. (1998). Differences in neurotoxic effects of ochratoxin A, ochracin and ochratoxin- $\alpha$ in vitro. Nat. Toxins. 6 (5):173-177.

Castegnaro, M., Barek, J., Fremy, J.M., Lafontaine, M., Miraglia, M., Sansone, E.B., Telling, G.M. (1991). Laboratory decontamination and destruction of carcinogens in laboratory wastes: some mycotoxins. Lyon, France: International Agency for Research on Cancer.

Chelkowski, J., Golinski, P., Godlewska, B., Radomyska, W., Szebiotko, K., Wiewiorowska, M. (1981). Mycotoxins in cereal grain. Part IV. Inactivation of ochratoxin A and other mycotoxins during ammoniation. Nahrung 25 (7):631-637. 
Creppy, E.E., Stormer, F.C., Roschenthaler, R., Dirheimer, G. (1983). Effects of two metabolites of ochratoxin A, (4R)-4-hydroxyochratoxin A and ochratoxin $\alpha$, on immune response in mice. Infect. Immun. 39 (3):1015-1018.

Elling, F., Nielsen, J.P., Lillehoj, E.B., Thomassen, M.S., Stormer, F.C. (1985). Ochratoxin A-induced porcine nephropathy: enzyme and ultrastructure changes after short-term exposure. Toxicon. 23 (2):247-254.

Fouler, S.G., Trivedi, A.B., Kitabatake, N. (1994). Detoxification of citrinin and ochratoxin A by hydrogen peroxide. J. AOAC Int. 77 (3):631-637.

Huwig, A., Freimund, S., Kappeli, O., Dutler, H. (2001). Mycotoxin detoxication of animal feed by different adsorbents. Toxicol. Lett. 122:179-188.

Li, S., Marquardt, R.R., Frohlich, A.A., Vitti, T.G., Crow, G. (1997). Pharmacokinetics of Ochratoxin A and Its Metabolites in Rats. Toxicol. Appl. Pharmacol. 145 (1):82-90.

Özpinar, H., Bilal, T., Abas, I., Kutay, C. (2002). Degradation of ochratoxin A in rumen fluid in vitro. Med. Biol. 9 (1):66-69.

Pfohl-Leszkowicz, A., Petkova-Bocharova, T., Chernozemsky, I.N., Castegnaro, M. (2002). Balkan endemic nephropathy and associated urinary tract tumours: a review on aetiological causes and the potential role of mycotoxins. Food Addit. Contam. 19 (3):282-302.

Piotrowska, M., Zakowska, Z. (2000). The biodegradation of ochratoxin A in food products by lactic acid bacteria and baker's yeast. Food Biotechnol. 17:307-310.

Pitout, M.J. (1969). The hydrolysis of ochratoxin A by some proteolytic enzymes. Biochem. Pharmacol. 18 (2):485-491.

Ratola, N., Abade, E., Simões, T., Venâncio, A., Alves, A. (2005). Evolution of ochratoxin A content from must to wine in Port-wine microvinifications. Anal. Bioanal. Chem. 382:405-411.

Ruhland, M., Engelhardt, G., Wallnofer, P.R. (1996). Transformation of the mycotoxin ochratoxin A in plants. 2. Time course and rates of degradation and metabolite production in cell-suspension cultures of different crop plants. Mycopathologia. 134 (2):97-102.

Samson, R.A., Hoekstra, E.S., Frisvad, J.C. (2004). Introduction to food-and airborne fungi. Utrecht, The Netherlands: Centraalbureau voor Schimmelcultures.

Schatzmayr, G., Heidler, D., Fuchs, E., Mohnl, M., Täubel, M., Loibner, A.P., Braun, R., Binder, E.M. (2003). Investigation of different yeast strains for the detoxification of ochratoxin A. Mycot. Res. 19:124-128.

Serra, R., Abrunhosa, L., Kozakiewicz, Z., Venâncio, A. (2003). Black Aspergillus species as ochratoxin A producers in Portuguese wine grapes. Int. J. Food Microbiol. 88 (1):63-68.

Stander, M.A., Bornscheuer, U.T., Henke, E., Steyn, P.S. (2000). Screening of commercial hydrolases for the degradation of ochratoxin A. J. Agric. Food Chem. 48 (11):5736-5739.

van der Merwe, K.J., Steyn, P.S., Fourie, L. (1965). Mycotoxins. Part II. The constitution of ochratoxins A, B, and C, metabolites of Aspergillus ochraceus Wilh. J. Chem. Soc. 7083-7088.

Varga, J., Rigó, K., Téren, J. (2000). Degradation of ochratoxin A by Aspergillus species. Int. J. Food Microbiol. 59 (1-2):1-7.

Wegst, W., Lingens, F. (1983). Bacterial degradation of ochratoxin A. FEMS Microbiol. Lett. 17 (1-3):341-344. 